\title{
Gürcüce-Türkçe Nezaket ve Hitap Kullanımındaki Benzerlikler ve Farklılıklar ${ }^{a}$
}

\author{
Burcu Meliha Keserb,c, Levan Pachulia ${ }^{\mathrm{d}}$
}

\section{Özet}

Bireyler arasındaki ilişkilerin ne olduğunu belirtmek ve kelimelere farklı değerler katmak için ifade edilebilen hitaplar, hemen hemen herkesin gündelik yaşamda kullandığı kelimelerdendir. Hitap, cümlelerden ve dil bilgisi ögelerinden bağımsız, konuşmaya yön verebilen daha çok kişiye atıfta bulunan söz öbeğidir. Gürcücede ismin hallerine dâhil edilen hitaplar, Türkçede edat, ünlem vb. konular içinde incelenmiştir. Türkçe ve Gürcücede kullanım sıklığına göre isimler, zamirler, sıfatlar ve fiiller hitap biçimleri sisteminde kullanılan sözcük türlerinden olduğu görülmüştür. Kişinin ya da ülkenin yozlaşması, dilin yozlaşmasıyla doğru orantılıdır ve bu mantıkla düşünüldüğü zaman hitap ve nezaket arasında önemli bir bağ olduğu ortaya çıkmıştır. Bu çalışmada araştırma metodu olarak doküman analizi kullanılmıştır. Gerekli alan yazın taraması yapılarak ortaya çıkan bilgiler doğrultusunda çalışmaya örneklerle destek verilmiştir. Gürcüce ve Türkçede kullanılan nezaket ve hitap biçimlerinin benzerliklerinin ve farklılıklarının ortaya çıarılması çalışmanın amacını oluşturmaktadır.
Anahtar Kelimeler

Nezaket

Hitap

Türkçe

Gürcüce

\section{Makale Hakkında}

Geliş Tarihi: 01.02.2021

Kabul Tarihi: 21.06.2021

Doi: $10.18026 /$ cbayarsos.637612

\section{Similarities and Differences in the Use of Politeness and Addresses in Georgian- Turkish}

\begin{abstract}
Addresses, which can be expressed to indicate what the relationships between individuals are and add different values to words, are among the words that almost everyone uses in daily life. An address is a phrase that refers to more people who can give direction to speech, independent of sentences and elements of grammar. Addresses included in Georgian noun cases, in Turkish prepositions, exclamations, etc. are topics that examined within. The degeneration of a person or a country is directly proportionate to the degeneration of the language, and when considered with this logic, it had been revealed that there is an important link between address and politeness. In this study, document analysis had been used as a research method. The study was supported with examples in line with the information that emerged by conducting the necessary literature review. The aim of the study is to reveal the similarities and differences of politeness and addressing styles used in Georgian and Turkish.
\end{abstract}

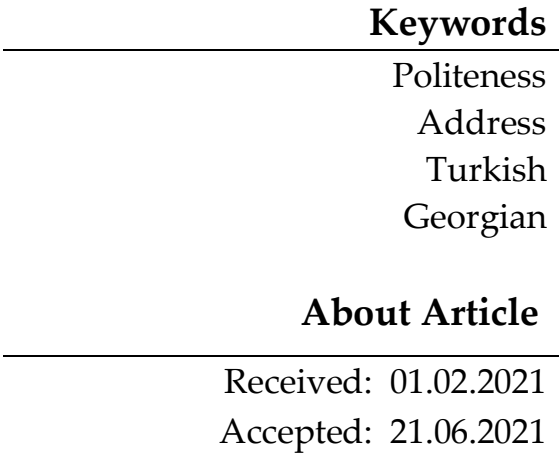

Doi: $10.18026 /$ cbayarsos.637612

\footnotetext{
a Bu makale Gürcüce ve Türkçe Hitap Biçimleri Sistemleri başlıklı doktora tezinden üretilmiştir.

b İletişim Yazarı: burcukeser01@gmail.com

c Doktora Öğrencisi, Gürcistan Sokhumi Devlet Üniversitesi, İnsani Bilimler Fakültesi, Gürcü Dil Bilimi Bölümü, ORCID: 0000-0002-7791-9862.

d Doç. Dr., Gürcistan Sokhumi Devlet Üniversitesi, İnsani Bilimler Fakültesi, Gürcü Dil Bilimi Bölümü. ORCID: 0000-0003-1424-0390.
} 


\section{Giriş}

Dil, tarih boyunca yeryüzünde yaşayan toplumlar (Aksan, 2004, s. 9) için en önemli iletişim aracı görevini üstlenmektedir. Ayrıca düşünceleri anlatmaya yarayan ve diğer insanlarla iletişim kurmayı sağlayan dilin sadece bireyle değil toplumla da çok sıkı bağları vardır (Zeyrek, 2009, s. 27). İki ya da daha fazla kişi arasındaki bilgi, fikir ve düşünce alışverişi olan iletişim, dilin en zor süreçlerinden biridir. İletişim halinde olan bireylerin yaş, eğitim, cinsiyet, hayat felsefeleri, mesajın gönderildiği yer, zaman ve mesajın amacı, mesajı iletirken kullandığı yöntem (sözlü, yazılı, vb.) gibi faktörler iletişim eyleminin anlaşılması için gereklidir (Kocaman, 2009, s. 7). Her zaman iletişim sürecine dahil olan en az bir muhatap veya alıcı söz konusudur. Yani iletişim için bir konuşmacının ve bir dinleyicinin olması gerekmektedir. Ayrıca konuşma konusu olmadan sözlü bir ilişki kurmanın imkânsız olduğu da bir gerçektir.

Bilgiler sözlü, yazılı ya da görseller aracılığıyla (görsel okuryazarlık) gönderilebilir / alınabilir. Buna uygun şöyle bir durum ortaya çıkmaktadır: Konuşmacı / dinleyici, yazar / okuyucu, görsel sunu / görsel okuma. Şüphesiz ki iletişim kuranların sayısı, duruma ve iletişim türüne göre değişiklik göstermektedir. İdeal bir iletişim kurmak için konuşmacının yalnızca kendi isteklerini (çıkarlarını) değil, aynı zamanda dinleyicinin isteklerini de (çıkarlarını da) dikkate alması gerekmektedir. Ayrıca tamamen bilgilendirici olmamasına rağmen iletişimde nezaket ve konuşmadaki görgü kuralları da büyük önem arz etmektedir. Konuşma görgü ve kurallarıyla nezaket gibi kavramlar konuşmada belirli bir kombinasyon oluşturmaktadır. Belirli bir topluluğun özelliği olan ve o topluluğun kendisi tarafından geliştirilen konuşma görgü ve kurallarıyla nezaket tarih boyunca değişmiştir. Konuşmadaki görgü kuralları, davranış normlarını belirlemektedir. İnsanlar çocuk yaştan itibaren çevresindeki bireylerle ilişkiler kurmaktadır. Bu ilişki türleri ise şöyledir: Büyük, küçük, yaşıt (akran).

İletişim ve iletişim yeterliliğinin yalnızca bir dilin dil bilgisi kuralları açısından doğru cümlelerin oluşturulması ve bunların doğru kullanımı üzerinde değil, aynı zamanda konuşmaciya bu cümleleri nerede, nasıl ve kiminle kullanacağını göstermede de önemli bir etkisi vardır. İletişim yeterliliği dil bilgisi doğruluğunun yanı sıra hem anlamsal hem de pragmatik doğruluğu kapsamaktadır.

Modern dil biliminde, bir yandan var olan dil bilimiyle ilgili konuların sistematik ve karmaşık çalışmasına, diğer yandan ise birbiriyle kesişen, disiplinler arası konularla ilgili araştırmalara gittikçe daha fazla önem verilmektedir. Bunlardan biri diyalojik konuşmanın önemli unsuru olan hitap konusudur.

İletişim açısından büyük bir yük taşıyan hitap biçimleri, iletişimde de önemli bir yere sahiptir. Hitabın doğru kullanılması, muhataplar arasındaki etkili iletişimin belirleyicilerinden biridir. Yanlış kullanılan bir hitap saygısızlık olarak düşünülmektedir ve iletişim üzerinde olumsuz bir etki yaratmaktadır (Karadoğan Doruk, 2010, s. 373). Muhataplar arasındaki anlaşmanın onların ortak paylaşımlarına bağlı olduğu da unutulmamalıdır. Sonuç olarak aynı dil ailesine mensup konuşmacıların farklı kültürlerden insanlarla iletişim sağlarken olası yanlış anlaşılmaların da olması yaygın bir durumdur. Farklı toplumların kullandığı hitaplar arasındaki başkalıkların nedeni ise kültürel farklılıklar, gelenekler, inançlar, sosyal ve politik sistemlerin de yanı sıra coğrafi konumdur. 
Her ulusun kendine özgü bir birlik faktörü vardır. Bu aynı zamanda hitabın ulusal ya da kültürel özelliğini de belirlemektedir. Hitap biçimi sadece dil bilimde değil, aynı zamanda sosyodilbilimde ve ahlak bilimde de iletişim sürecine dâhil olan her kişiye karşı farklı dil bilimsel açılardan ele alınması gereken bir konudur. Bu sözlü iletişimde hem düşünce ifadesinin yeterliliğinin hem de geleneksel olarak oluşturulmuş görgü kurallarına uymanın gerekli olduğu gerçeğiyle açıklanmaktadır. Tarih içerisinde gelenekler, etik kurallar ve davranışlar her ulusta normları oluşturmuştur. Bu durum dile yansıtılmakla birlikte aynı zamanda görgü kurallarını da belirlemiştir. Hemen hemen tüm kültür ve dillerde saygı, nezaket ve görgü kurallarını geliştirmek için farklı şekillerde hitapların kullanımı tercih edilmiştir.

Dil bilim literatüründe hitabın bazı tanımları mevcuttur: Örneğin Quirk'e göre seslenme: "Bir cümle veya tümceye isteğe bağlı olarak eklenen, bir veya birden fazla kişiye atıfta bulunan ve onlara hitap ettiğini işaret eden nominal bir unsurdur" (Quirk , 1973, s. 182).

Kvachadze'ye göre: “Hitap edilen kişiyi gösteren ayrı kelime veya kelimeler grubuna hitap denmektedir" (33ऽłsdj, 2010, s. 319).

Peikrishvili'ye göre hitap: “Cümlede kişi ya da nesneyi belirtmek için kullanılan ve

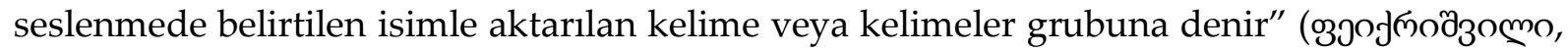
1996, s. 216). Peikrishvili hitabı, dil bilgisi açısından cümleyle bağlantısı olmayan kelimeler ve ifadeler grubuna dâhil etmektedir.

Hitap, tek bir şahsı göstermesine rağmen, bir gruba veya bir topluluğa karşı da yapılan bir tür seslenme biçimidir (Dragolovcanin, 1997, s. 56).

Herhangi bir diyaloğa ya da yazılı bir metne başlarken bahsi geçen metnin muhatabını işaret ettiği seslenme şekilleridir (Oğuz, 2011, s. 1203).

İngilizce uygulamalı dil bilim sözlüğündeki hitap şu şekilde açılanmıştır: "Konuşma veya yazmada birisine hitap etmek için kullanılan kelime veya tamlamalardır" (Longman Dictionary of Language Teaching And Applied Linguistics, 2010, s. 11).

Rus dili açıklayıcı sözlüğünde ise hitap için şu ifadeler yer almaktadır: "Konuşma esnasında hitap edenin alıcısına atıfta bulunduğu kelime veya ifade biçimidir. Bir nevi iletişim tarzıdır. Konuşmanın yönlendirildiği bir kişiyi (az da olsa nesneyi) adlandıran kelime veya kelimeler kombinasyonudur" (Большой современный толковый словарь русского языка, 2012).

Yıldırım ise hitabı şöyle açıklıyor: “Dilin söz varlığı içinde önemli bir yere sahip olan hitaplar, seslenme, sayg1, sevgi, sitem, heyecan, aşk gibi belirli duyguları anlatmak için kullanılan sözcüklerdir" (Yıldırım, 2017, s. 123).

Hitaplar, seslenen tarafından alıcısının dikkatini uyandırıp konuşmaya çekmek, onun konuşmaya olan alakasını devam ettirmeyi sağlamak amacıyla kullanılan, içinde hitap eden kişinin duygu, düşünce ve maksadını barındıran genellikle tümce başı vurgulu kelime türleridir (Alkan Ataman, 2018, s. V).

Hitap terimi, belirli bir sözdizimsel birimin ayrı türlerinden biri olan ismi belirtmek için kullanılmakta ve genellikle ismin seslenme biçimini veya onu ihtiva eden tüm yapıyı ifade 
etmektedir. Bu tanımlamaların geneli tekdüze değildir ve hepsi hitabın farklı taraflarına dikkat çekmektedir.

\section{Yöntem}

Bu çalışmada Gürcüce ve Türkçede kullanılan hitaplar ve nezaket kuralları üzerine bir karşılaştırma yapılmıştır. Gürcü dilinde ve Türk dilinde kullanılan nezaket ve hitap biçimlerinin benzerlik ve farklılıklarının tespit edilmesi çalışmanın amacını oluşturmuştur. Doküman analizi çalışmanın araştırma metodu olarak kullanılmıştır. Konular hakkında gerekli alan yazın taraması yapılmış ve ortaya çıkan bilgiler doğrultusunda çalışma örneklerle desteklenmiştir.

Gürcüce dil bilgisinde ve dil bilim çalışmalarında hitabın, cümlenin hiçbir ögesiyle ilgisi olmayan ayrı bir kelime olduğu belirtilmektedir. Sharshovani'nin (1881) dil bilgisinde hitap seslenme hali olarak açıklanmıştır. 1.Anton (1885) ise hitaptan ayrıntılı olarak bahsetmektedir ve onu "o- 9" (hoe) gibi işaretlere ayırmaktadır. Fakat bu şekilde de seslenme hitap şekli olarak kabul edilmemektedir. İlerleyen zamanlarda Gürcü dilinde hitap biçimini ilk fark eden Solomon Dodashvili olmuştur. Ancak Dodashvili hitabın gramer analizini yapmamış ve hitaba karşılık gelen uygun bir terim vermemiştir.

Chubinashvili, 1887 yılı dil bilgisinde ilk olarak, seslenme halinde olan ismin cümle içinde ayrı olarak yer aldığını ifade etmiştir. Jordan'i (1889) ise hitabı ilk kez kendi ders kitabında doğru gramer niteliğinde olan ayrı bir kelime olarak göstermektedir. Terim olarak ise göreceli veya seslenme kelimesini tanıtmaktadır. O zamandan beri neredeyse tüm dil bilimciler birkaç terminolojik farklar olsa da hitabı ayrı bir kelime olarak görmektedir

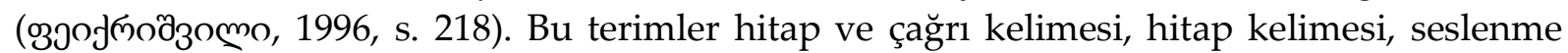
kelimesi, seslenme veya hitap sözcüğü, ünlem sözcüğü ve hitaptır. Bugün Gürcü dilinde hitap, seslenme haline yerleşmiş bir isimdir; ancak hitap biçimi her zaman aynı olmamaktadır. Eskiden Gürcücede, hitap için ismin kökü kullanılır ve buna bazı durumlarda "g" (hoe) ünlemi eşlik ederdi. Fakat daha sonra bu ünlemin eskimesiyle birlikte "o" seslenme

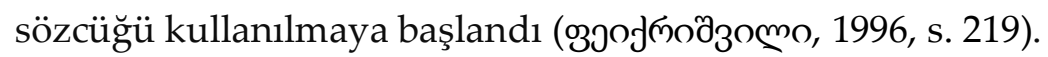

Hitap, cümlelerden ve dil bilgisiyle alakalı olan ögelerden bağımsız, konuşmaya yön verebilen daha çok kişiye ve nadiren de olsa nesnelere vurgu yapan bir söz öbeğidir. Aslında nesnelerden ziyade daha çok muhataba atıfta bulunan, muhatabı adlandıran kelimelerin birleşimidir. Hitap biçimleri Gürcü dilinde ve Türk dilinde sözcükler, şiirler ve deyimler vasıtasıyla sözlü iletişim sırasında bir konuya ya da bir kişiye atıfta bulunmak için kullanılmaktadır. Ayrıca bireyler arasındaki ilişkinin düzeyinin ne olduğunu belirtmek ve kelimelere farklı değerler katmak için de kullanılmaktadır. Hitap biçimlerinin pek çok vazifesi olmasına rağmen esas görevi muhatabı iletişim ortamına çekmektir. Başka bir deyişle muhatap olunan kişinin dikkatini çekmektir. Dikkat çekme görevi ise genellikle cümlenin başında gerçekleşmektedir. Herhangi bir ayrım gözetmeksizin (eğitim, pozisyon vb.) herkes tarafından kullanılan hitaplar belirli kriterlere (yaş, sosyal statü, cinsiyet) ve bireyin hitap ederken ki niyetine göre değişmektedir.

Türkçe ve Gürcücede hitap ederken kullanılan ekler, kelime çeşidi ve hitabın cümlede bulunduğu pozisyonu hakkındaki çalışmalar oldukça azdır. Hitaplar, dillerin sözcük varlığında çeşitli şekillerde yer almıştır. Gürcücede hitaplar, kendine özgü birtakım ögelerle ifade edilebilmektedir. Bu açıdan sözcük dizisi ve sözcüğün kullanım şekli, hitabın ifade 
edilmesinde büyük önem taşımaktadır. Gürcücede ismin hallerine dâhil edilen hitaplar seslenme hali olarak da adlandırılmaktadır. Diğer ismin hallerinin aksine seslenme hali ne kelimeleri bağlamada ne de fiil yapılarını bağlamada kullanılmaktadır. Böyle bir göreve sahip olmayan hitaplar herhangi bir sözcük türü tarafından da yönetilmemektedir. Genel olarak Gürcü dilinde hitapları, seslenme hal eki işaretleriyle (o- v), sözcüklerle, uygun noktalama işaretleriyle, ünlemlerle ve tonlama ile ifade edilebilmek mümkündür. Kimi dillerde var olan seslenme hali Türkçede olmadığı için hitaplar biçim bilgisi temel alınarak sözcük türleri kapsamında ayrı başlıklar içerisine dâhil edilip ünlem, ilgeç ve cümle dışı öge olarak ele alınmıştır.

Kimi dilciler seslenmeleri edatlar konusuna dâhil ederken kimi dilciler de hitapları ünlem grubunun içerisine dâhil etmişlerdir. Dil bilimi kapsamındaki araştırmalara konu olan hitaplar dil bilimiyle ilgili kaynaklarda farklı bir bölümde anlatılmamıştır.

Genel olarak bakıldığında Türkçede hitapların ünlemler konusu adı altında incelendiği ortaya çıkmaktadır. Ünlemler, hitap için kullanılan dil birimlerini ifade etmesi yönünden güçlendirici ve betimleyici unsurlardır. Biçim bilgisi açısından güçlendirme görevini, sanki bir tümleyen- tümlenen ilişkisi içerisindeymiş gibi gerçekleştirmektedir. Seslenme ögeleri ve ünlemler arasında şekil ilişkisi vardır (Korkmaz, 2009, s. 1178-1179). Ünlemler belirli bir duyguyu ya da düşünceyi hitaplar aracılığıyla anlatabilmektedir. Ayrıca burada vurgu ve tonlama önemlidir. Hitaplar genellikle insanların kendi adlarını (Antroponyms), akrabalık bağlarını, cinsiyetini, yaşını, unvanını, mesleğini ve pozisyonunu ifade eden kelimeleri içermektedir.

\section{Bulgular}

Hitapların kullanımına ilişkin örnekler günlük konuşmalarda ve yazılı metinlerde görülmektedir. Kültürel değerlerin belirlenmesinde de hitap biçimleri çok önemlidir. Edebi metinlerde, özellikle şiirsel anlatımlarda, soyut nesneler ve konuşma yetisi olmayan canlılar (hayvanlar, bitkiler) veya cansız varlıklar için kullanılan isimler hitap rolünde ortaya çıkmaktadır.

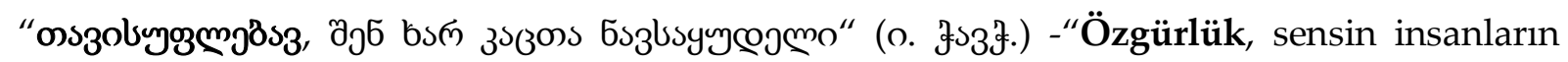
liman1".

Buradaki örnek cümlede soyut bir kavram olan "özgürlük” hitap rolünü üstlenmektedir.

Bazı dil bilimciler hitapları cümle dışı öge olarak kabul etmektedir. Bunlardan biri Leyla Karahan'dır. Leyla Karahan cümle dışı ögeleri şöyle aktarmaktadır: "Cümlenin anlamına katkıda bulunan unsurlardır ve cümlenin yapısına katılamazlar. Başka bir deyişle cümlenin ögesi olamazlar. Bağlama edatları, ünlem edatları, ünlem grupları, hitaplar, ara sözler cümle dişı unsurlardır"' (Karahan, 2010, s. 21-36-37).

Ey mermeri nakış nakış işleyip konuşturan (ünlem grubu);

Ulularım (hitap), neredesiniz? (Karahan, 2010, s. 37) cümlesindeki “Ey mermeri nakış nakış işleyip konuşturan ulularım!" hitap ve ünlem grubudur. 
Bir diğer dil bilimci ise JuJuna Peikrishvili'dir. Peikrishvili cümle dışı ögeleri şu şekilde tanımlamaktadır: "Gramatik olarak cümlenin ögeleriyle bağlantısı olmayan ve onlardan tamamen ayrı duran kelime ve ifadelerdir". Peikrishvili hitabı, ekleri, türemiş bağlaçları,

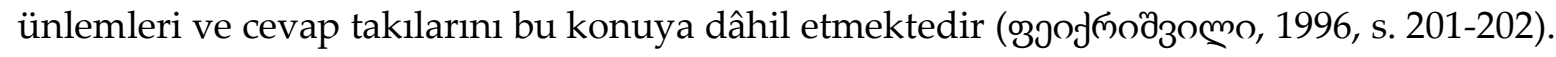

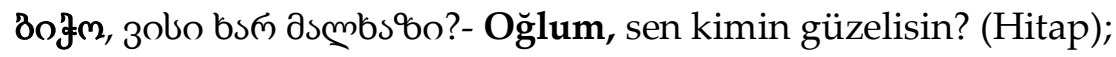

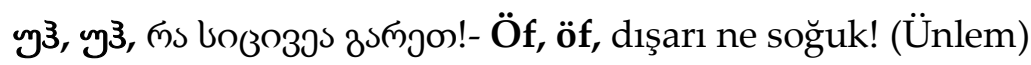

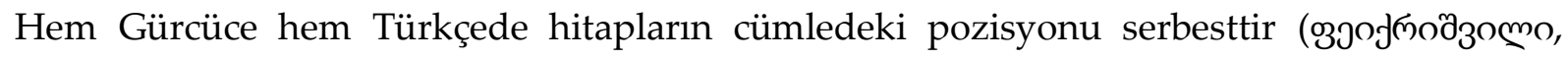
1996, s. 218). Yani cümlenin başında da, ortasında da, sonunda da yer alabilmektedir. Cümlenin başında bulunan hitapların dikkat çekme görevi vardır. Cümle ortasında veya sonunda yer alan hitaplar ise temel olarak sosyal mesafenin bir ifadesidir. Cümlede kullanılan hitapların tonlamasına göre noktalama işaretleri değişmektedir. Hitaplar yüksek bir tonla söylendiğinde ünlem işareti, alçak bir tonla söylediğinde ise virgül işareti konmaktadır. Bu işaretlerden başka herhangi bir noktalama işareti kullanılmamaktadır.

Cümlenin başında kullanılan hitaplardan sonra virgül veya ünlem işareti gelmektedir.

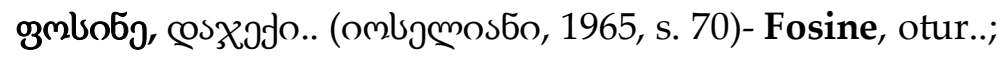

Efendiler, bilirsiniz ki hayat demek, mücadele, müsademe demektir (Atatürk);

Ordular! İlk hedefiniz Akdeniz'dir, ileri! (Atatürk);

Anneciğim! Saçların çok güzel olmuş.

Ĕger hitaplar cümlenin ortasına kullanılıyorsa, her iki taraf virgülle ayrılmaktadır.

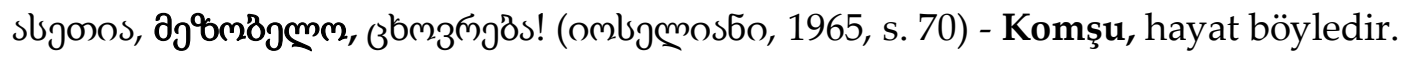

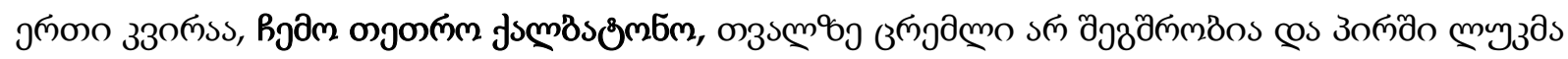

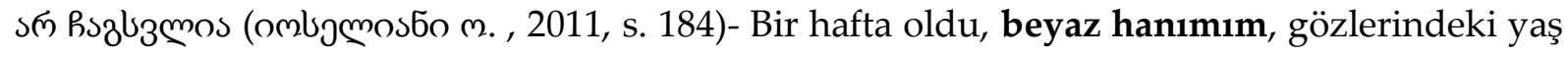
kurumadı ve bir lokma ağzına girmedi.

Ruhumun senden, İlahi, şudur ancak emeli (Karahan, 2010, s. 38) .

Hitaplar cümlenin sonunda kullannlıyorsa ondan öncesinde virgül işareti gelmektedir. Sonrasında cümledeki tonlamaya göre ünlem işareti, iki nokta veya soru işareti konmaktadır.

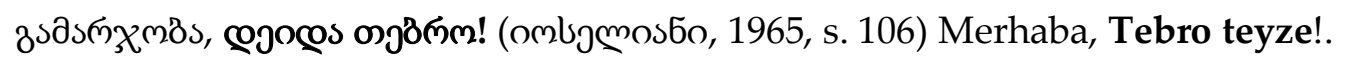

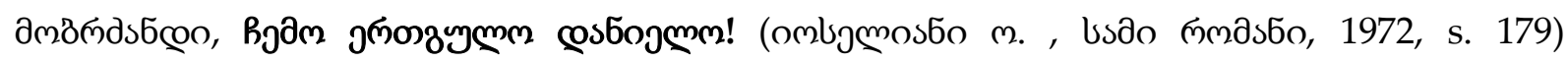
Buyurun, benim sadık Daniel'im!.

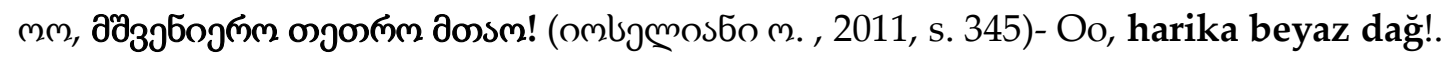

Eski gazeteleri bana verir misin, teyze? (Karahan, 2010, s. 38).

İlahi bir kudretin, ebedi bir feyzin var, ey Türk! (Ahmet Hikmet Müftüoğlu). 
Hitaplar ya cümlenin yapısına dâhil edilmektedir ya da cümleden ayrı durmaktadır (33słsdo, 2010, s. 319).

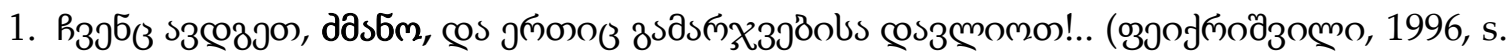
216) Biz de ayağa kalkalım, kardeşlerim, ve bir de zaferimize içelim!.

Benim mi Allah'ım bu çizgili yüz? (Karahan, 2010, s. 38).

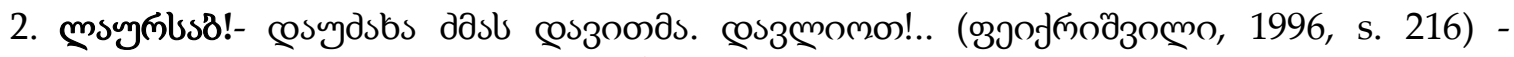
Laursab! David kardeşini çağırdı. İçelim!

Hasan! Ayşe çantasını nereye bıraktı?

Birinci örnekteki hitaplar cümle yapısına dâhil edilirken, ikinci örnekteki hitaplar cümleden ayrı durmaktadır.

Hitapla doğrudan alakası olan ögeye, açıklayıcı ve benzeri bir kelime eşlik etmektedir (33słsdo, 2010, s. 320).

Ey mermeri nakış nakış işleyip konuşturan

Ulularım, neredesiniz? (Karahan, 2010, s. 37).

Eyüb, Türklerin ölüm şehri Eyüb, Avrupa toprağının bittiği sahilde İslâm cennetinin bir bahçesi gibi yeşil duruyor (Karahan, 2010, s. 20).

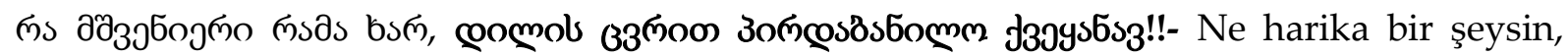
sabahın nemiyle yüzünü yıkayan ülke!! (33 łsdj, 2010, s. 320).

Örneklerde hitaba basit bir ek, bir öge veya bu ögeye bağlı bir sözcüğün de eşlik ettiği görülmektedir. Yani cümlenin ana ögesi olmayan unsurlar da hitabın yanında yer alabilmektedir. Ancak hitap herhangi bir ögeye gramer olarak bağlı değildir ve cümlenin ögesi de sayılmamaktadır. Bundan dolayıdır ki hitap kendisine bağlı olan ya da bağlı olmayan kelimelerle cümle içinde tamamen ayrı bir yere sahiptir.

Hitapları tek kelimeyle aktarabileceğimiz gibi yanında olan kelimelerle de genişletebilmek mümkündür. Bazen hitap ve hitaba eşlik eden ögeler birbirinden bağımsız olabilmektedir.

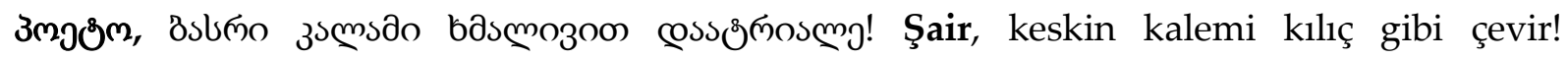

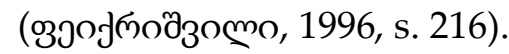

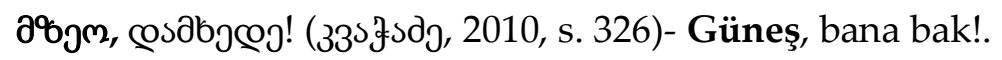

Sana dün bir tepeden baktım, aziz İstanbul (Karahan, 2010, s. 37).

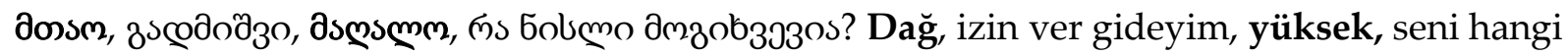

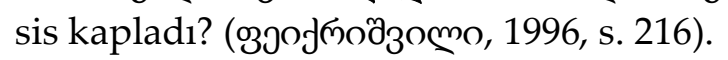

Genç! Ne de zayıfsın, hadi şuna bir el at da taşıyalım delikanlı.

Seslenme hal eki veya ekleri hitaba eşlik etmektedir. Türkçede seslenme hal eki olmadığ için bu tarz bir kullanım görülmemektedir. Ayrıca hitaplar anlatımı güçlendirmek için tekrar edilebilmektedir. 


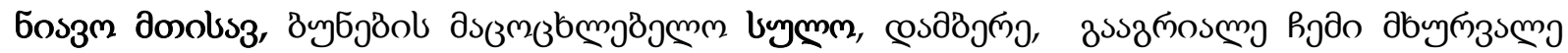

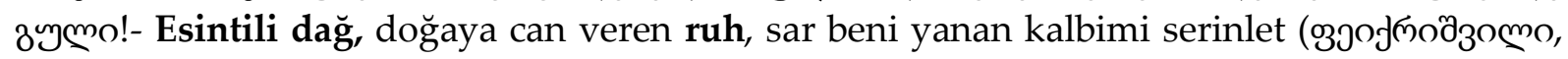
1996, s. 216).

Dağlar dağlar, kurban olam, yol ver geçem sevdiğimi son bir olsun yakından görem (Barış Manço).

A dağlar ah ulu dağlar (Tamaşvarlı Gazi Âşık Hasan).

Hem Türkçe hem Gürcücede hitap biçimleri sisteminde yaygin olarak kullanılan isimler ilk sırada yer almaktadır. Genel olarak hitaplar isimler aracılığıyla aktarılmaktadır. Fakat ismin eksik olduğu hitaplarda devreye sıfatlar ve zamirler girerek isim göreviyle kullanılmaktadır. Konuşmacı genellikle ikinci kişiye atıfta bulunmaktadır. Bu nedenle insanların kendi isimlerinin yanı sıra akrabalık, cinsiyet, rütbe, meslek, yaş ve pozisyonu ifade eden kelimelere atıfta bulunmak çok yaygındır. Ayrıca hitabın kullanım alanlarına sloganlar, diyaloglar, davetler, selamlamalar-vedalaşmalar, özel ve genel yazışmalar da dâhil edilmektedir.

Hitap olarak kullanılan insan isimlerinden kısaca bahsetmek gerekirse, bu hitaplar muhatabın yaşına, sosyal statüsüne, cinsiyetine, yakınlık derecesine vb. durumlara göre değişiklik göstermektedir ve hitap ederken bu koşulların da dikkate alınması gerekmektedir. $\mathrm{Bu}$ durum konuşmacının ve muhatabın arasındaki iletişimin sağlıklı olması için önemli bir etkendir. Bahsedilen dillerde insan isimlerinin kısaltılmış hali de mevcuttur (nati, gio, salo, ozi, apo, İbo vb.). Bu isimler hitap olarak karşımıza çıkmakta ve bunları genellikle aile bireyleri, arkadaşlar ve yakın olan tanıdıklar kullanmaktadır. Kişilerin arasında bu tarz kullanımların olması aradaki yakınlık derecesinin fazla olduğunu göstermektedir. Hitap sırasında kullanılan bir başka isim ise takma adlardır. İnsanlar tarafından oluşturulmuş alternatif bir isimdir. Bunlar genellikle kişi adlarından bağımsız olmaktadır. Fakat tamamen de gelişigüzel verilmemektedir. Bireyin birkaç özelliğinden esinlenerek meydana gelmektedir. Çünkü bunlar kişinin yapısını ve mizacını ortaya koyan ifadelerdir. Eski zamanlarda takma adlar genellikle devlet büyükleri, sanatçlar, yazarlar ile aktörler ve müzisyenler tarafından kullanılır ve onlara takma adlarıyla hitap edilirdi. Şimdilerde ise hemen hemen herkesin kullandığı bir seslenme biçimi haline gelmiştir.

Günlük hayatta her iki dilde de çok sık karşılaşılan fakat hitap olarak neredeyse çok az kullanılan soyadları askeriyelerde, okullarda (yabancı öğretmenlerin öğrencilere veya öğrencilerin yabancı öğretmenlere seslenmeleri, velilerin öğretmene ya da öğretmenin velilere soyadıyla seslenmeleri) sizli bizli diyaloglarda, TV programlarındaki (ya da haberlerdeki) spikerlerin ve konuşmacıların muhataplarına karşı (resmiyet maksadıyla) seslenmelerinde, köklü aile mensuplarına (Sabancı, Koç vb. gibi) karşı kullanılan hitaplarda ve diğer resmi durumlarda görülmektedir. Gürcücede soy ismin kökünün ünsüzle bitmesi halinde seslenme hal eki "o" eklenirken ünlüyle bitmesi durumunda ise soyadları yalın halde kalmaktadır (baratashvil-baratashvil- o, putkaradze- Ø). Türkçede ise hitap anında soyadları hep yalın halde kullanılmaktadır.

Hitap olarak kullanılan toplum isimlerinden bahsetmek gerekirse, sadece belirli bir konu ya da nesneyi değil birden çok konuya veya nesneye atıfta bulunabilen ifadelerdir. Hitap eden kişilerin muhataplarının toplumdaki sosyal statüsüne göre kullandıkları hitaplardır. Toplum 
isimlerinde günlük hayatta yabancıya hitap eden bazı formların kullanımına neredeyse az rastlanılmaktadır. Örneğin "adam" kelimesi erkeğe seslenmek için kullanılan ifadeler arasında yer almaktadır. Günlük hayatta nadiren karşılaşılan hitaplardan biridir. Kullanıldığ1 takdirde ünlem görevini üstlenmektedir. Gürcücede kadınlara da hitap olarak kullanıldığ 1 görülmektedir.

Aile bireyleri için kullanılan seslenmeler genellikle sevgi ve şefkat ifade etmektedir (kişilerin birbirlerine sinirli olma durumunda kullanılan hitaplar tamamen değişmektedir. Örneğin annenin çocuğuna kızınca adıyla ve soyadıyla seslenmesi vb. gibi). Bireylerin birbirleriyle iletişim halindeyken kullandıkları seslenmeler ya yalın halde ya sevgi belirten küçültme ekleriyle (-cik, -ciğim, oзm (iko), omm (ilo) vb.) ya da aile bireyleri için kullanılan terimlerin kısaltılmış haliyle ifade edilmektedir. Bu terimlerin kısaltılmış hali sadece Gürcücede görülmektedir. Türkçede ise böyle bir seslenme biçimi söz konusu değildir. Mesela dedaanne: bir çocuğun annesine seslenmesi durumunda "deda" hitabı ya kısalmaktadır ya küçültme eki gelmektedir ya da yalın halde kullanılmaktadır. De (kısaltma), ded-iko, ded-ilo (sevgi bildiren küçültme eki- annecim), deda (yalın hal). Aslında her iki dilde de hitap için ifade edilen küçültme eklerinin kullanım alanı kısıtlıdır.

Akrabalık bildiren ifadelerde hitap biçimlerinin oldukça sık kullanıldığı görülmektedir (teyze- deida, hala- mamida, dayı,-bidza amca- bidza, dede- babua, ananene- bebia, babaanne- bebia vb.). Ancak onların tanıdık olmayan kişiler için de hitap ederken kullanıldığı bilinmektedir. İletişim esnasında hitap ederken bu tarz bir kullanımın olması muhataba karşı nezaket ve sıcaklık ifade etmektedir. Bu hitaplar genellikle ya isme gelmekte ya da tek başına kullanılmaktadır (Hayriye teyze ya da sadece teyze). Gürcücede ise bu hitapların hem ismin önünde hem de ismin arkasında kullanıldığ 1 görülmektedir (deida lia (ad), elene (ad) deida vb.). Bu konu hakkında başka bir durum ise, Gürcücede yenge ve hala gibi akrabalık bildiren hitap ifadelerinin ikinci bir kullanımının bulunmamasıdır. Başka bir deyişle onlar sadece akrabalara hitap ederken ifade edilmektedir. Türkçedeki gibi yakın olan tanıdıklara veya yabancı kişilere kullanılması Gürcücede söz konusu değildir.

Gürcüce ve Türkçede akrabalık terimlerini ayrıntılı bir şekilde anlatan sözcükleri görmek muhtemeldir. Görümce, baldız, kayın, bacanak, elti gibi kelimeler göreceli kavram olduklarından dünyadaki birçok dildeki kelimelere doğrudan karşılık gelmeyebilirler. Elbette dünyadaki diller arasında akrabalık terimlerini bu kadar detaylı bir şekilde ifade eden başka diller de vardır. Mesela her iki dilde de kullanılan "torun" kelimesi, bir kişinin oğlunun veya kızının çocukları için kullanılan genel bir terimdir ve farklı bir sözcükle ifade edilmemektedir. Ancak konuşulan bazı dillerde durum böyle değildir. Torun sözcügünü ifade etmek için bireyler ayrı ayrı kelimeler kullanmaktadır.

Türkçede akrabalık isimleri çok çeşitlidir ve bunlardan bazılarının birden fazla eş anlamlısı vardır. Mesela, ana- anne- valide- māder, amca- emmi- emice, hala- bibi (eski. Hanım, hanımefendi demek), -cice- kız kardeş- hemşire- bacı, baba- peder- dede vb. (Ayverdi, 2010) gibi verilen örnekler hitap veya seslenme olarak ifade edilmektedir.

Hayır, hemşireciğim, telefon haber vermedi (Ahmed Midhat Efendi) (Ayverdi, 2010, s. 496). 
Türkçede akrabalık ifade eden amca ve dayı hitaplarının ayrımına Gürcücede rastlanılmamaktadır. Çünkü Gürcü dilinde bu terimler tek bir kelimeyle ifade edilmektedir (bidza - Bods). Bu da Türkçenin kelime hazinesinin ne kadar geniş olduğunun göstergesidir.

Çeşitli meslek dallarının da hitap biçimi olarak kullanıldı̆̆ı görülmektedir. Hem Türkçe hem Gürcücede bazı meslek isimleri birtakım ekler aracılığıyla oluşturulmaktadır (c1 -ci, -cu, -çı, çi, -çu -me- e, me- ur (me- ul), mo-e). İsmin köküyle belirtilen bu ekler belirli bir nesne ya da

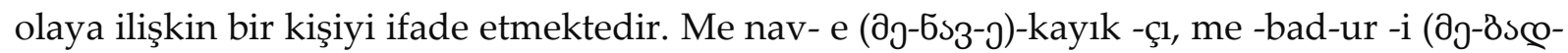

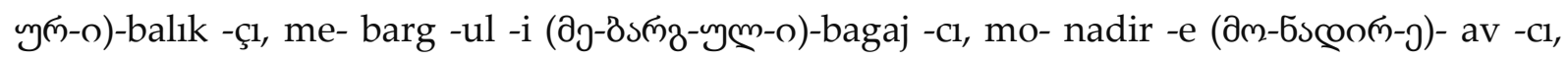

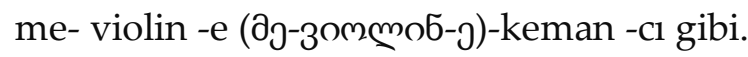

Unutulmaz bu ac1,

Dertli dertli çal keman-cı (Mehmet Yüzüak).

Ne Gürcüce ne de Türkçede gramer açısından cinsiyet kategorisi bulunmamaktadır. Gerçek cinsiyet özel isimle belirtilmektedir (Rojmठ̊s3s, 1998, 33. 24). Fakat bazı kelimeler gramer açısından olmasa da sözlük ve anlam bakımdan cinsiyet ifade etmektedir. Başka bir deyişle bahsedilen kelimeler sadece erkek veya dişi varlıklar için kullanılmakta ve bu varlıkları işaret etmektedirler (erkek varlıklar; baba, amca, dayı, oğlan, koca, dede vb. dişi varlıklar; anne, abla, gelin, görümce, baldız, hala, teyze vb.). Bu varlıkların hepsi birer hitap biçimi olarak kullanılmaktadır.

Her iki dilde hitap biçimi olarak kullanılan soyut isimler, sözcügün kök ve gövdelerine belirli ekler getirilerek de ifade edilmektedir (son ek -oba- eba, ön ek ve son ek; si- e, -lik, -lik -lük vb.). Hitap olarak günlük hayatta nadiren kullanılan soyut isimler, daha çok edebiyatta özellikle de şiirde geçmektedir.

Gürcü dilinde ve Türk dilinde seslenme biçimi olarak kullanılan zamirler daha çok ikinci şahıs zamirleridir (sen- siz, shen- tqven) ve bunlar muhatabı ya da muhatapları belirtmektedir. Bu zamirlerin hitabı iletme görevi yoktur. Çünkü hitabı iletme görevini 1. şahıs zamirleri üstlenmiştir. Daha çok hitap edilen kişinin niteliksel özelliklerini gösteren isimlere eşlik etmektedir. Şahıs zamirlerinin tekrarlandığ 1 da görülmektedir (33ऽłsdð, 2010, s. 321). Bu zamirler birbirlerinin yerine kullanılmaktadır. Ayrıca anlama resmiyet ve saygı ifadeleri yüklemektedir. Bahsi geçen dillerde hitap biçimlerinde iyelik zamirleri de oldukça yaygındır ve hitapla beraber kullanılmaktadır.

Şu andan itibaren dikkatli ol, oğlum.

Gürcücede ikinci tekil ve çoğul şahıs zamirlerinin (shen (sen)- (siz) tqven) son sesinin çıkarılması sonucunda oluşan belirli bir yapı vardır ve bu yapı oldukça yaygın kullanılmaktadır. Bu yapıda ikinci şahıs zamirleri genellikle "n" sesinden ayrılmaktadır. Böyle bir hitap biçimi, konuşma dilinin özelliğinden kaynaklanmaktadır. İkinci şahıs zamirlerinden ayrılan "n" sesi anlamda herhangi bir değişikliğe neden olmamaktadır (33 Jłsdy, 2010, s. 321). Türk dilinde hitap olarak kullanılan ikinci şahıs zamirlerinde herhangi bir düşme veya çıkarılma söz konusu değildir.

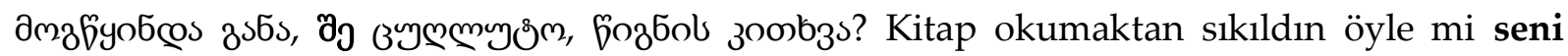
yaramaz? 


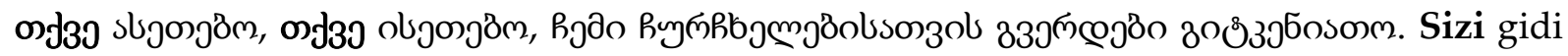
sizi gidi yaramazlar, benim sucuklarımın yanlarını acıtmışsınız (33 łjsdj, 2010, s. 321).

Dönüşlü zamir olan "kendi" bir şahsı belirttiği için hitap olarak ifade edilmektedir. Buna ikinci şahıs zamiri olan "sen" de eşlik edebilmektedir (isteğe bağlı olarak). Konuşan kişinin bazen kendine hitap ettiğini de göstermektedir.

Yemeği kendim yaptım.

Bunu kendin istedin.

Bu örneklerde zamir cümlenin anlamı içinde gizlidir.

Hitap olarak kullanılan sözcük türlerinden biri de sıfatlardır. Sıfatlar adlardan önce gelerek onları belli özelliklere göre vasıflandıran veya belirten sözcüklerdir. Hitaplar daha çok niteleme sıfatları aracılı̆̆ıyla ifade edilmektedir ve bunlarda olumlu ya da olumsuz değerlendirme de söz konusudur. Örneğin; sevgilim, hayatım, tatlım, güzelim, aptal, yalancı, deli, şişko gibi. Genel olarak bakıldığında bu değerlendirmelerin akrabalara, aile bireylerine ve tanıdıklara seslenirken kullanıldığı görülmektedir.

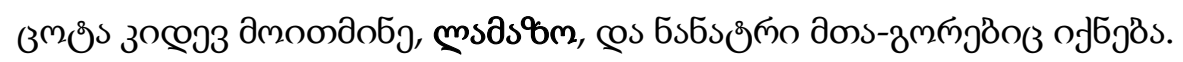

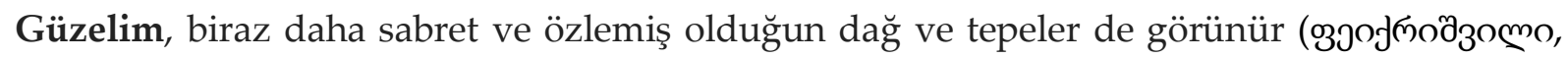
1996, s. 217) (“Güzel-im” senli benli konuşmalarda -im iyelik ekinin kalıplaşması sonucunda ortaya çıkan hitap sözcüğüdür).

Hitaplar sadece isimle ifade edilmeyen aynı zamanda fiille de ifade edilebilen sözcüklerdir. Hitap olarak kullanılan fiiller tıpkı isimlerde ve sıfatlarda olduğu gibi seslenme işlevini yerine getirmektedir. Genellikle bu fiiller dilek kiplerine dâhil olan emir kipiyle kullanılmaktadır ve bilindiği üzere emir kiplerinin herhangi bir eki bulunmamaktadır. Sadece fiillere getirilen ikinci çoğul şahıs ekleri [in ${ }^{(4)-}$ iniz ${ }^{(4)}, \mathrm{t}-\infty$ (Gürcüce)] emir kipine eşlik etmektedir. Her iki dilde de hitap sırasında ikinci tekil kişi için fiillere getirilen herhangi bir ek söz konusunu değildir. Ayrıca emir kipinin ikinci çoğul ekiyle (iniz- t (o) kullanılması rica ve nezaket anlamı taşımaktadır.

Otur!- cosxojo!

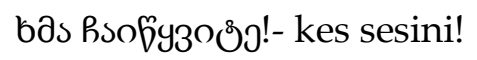

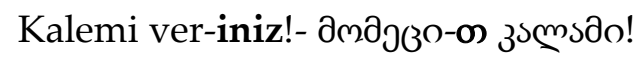

Gel buraya!- sł dmœo!

\section{Nezaket}

Toplumsal ilişkilerin kazandırdığı normlar sonucunda ortaya çıkan "nezaket" toplum tarafından kabul gören ve düzenlenen, toplum üzerinde çok büyük bir etkiye sahip olan davranış biçimidir. Bireyin veya ulusun yozlaşması, dilin yozlaşmasıyla doğru orantılıdır. $\mathrm{Bu}$ mantıkla düşünüldüğü zaman hitap ve nezaket arasında önemli bir bağ olduğu anlaşılmaktadır. Eski kültürlere sahip birçok ülkede hitap ve nezaket sosyal seviye açısından belirli bir hiyerarşik ilişkiden önce gelmektedir. Nezaketin anlamı konusunda bazı 
farklılıklar vardır. Kimi insanlar nezaketi saygı olarak tanımlarken kimisi de bunu iyi bir ifade biçimi ya da uygun davranış biçimi olarak tanımlamaktadır.

Bazı antropologlar tarafından önerilen ve yüz kavramına dayalı olan 4 tane nezaket türü vardır. Bunlar dolaylı, dolaysız, olumlu ve olumsuz nezakettir. Dolaylı nezaket, üstü kapalı bir nezaket stratejisidir. Yani imaya dayanmaktadır. Konuşmacının tehdit edici eylemle dolaylı olarak yüzleşmesine izin veren bir stratejidir. Dolaysız nezaket herhangi bir şeyin dayatmasını en aza indirmeden, açık, net ve özlü bir şekilde söylemenin doğrudan bir yoludur. Olumlu nezaket dinleyicinin olumlu yüzüne yönelik tehdidi en aza indirmeye çalışmaktadır. Ayrıca konuşmacı muhatabının bazı isteklerini beğendiğini ima ederek yüz tehdit etme eylemini en aza indirmeyi amaçlamaktadır. Negatif nezaket alıcının isteklerinin daha az ihlal edilmesi durumudur. Bir başka deyişle kişinin isteklerini özgürce yapma hakkına saygı duymaktır. Her nezaket stratejisi, hem konuşmacıyı hem de dinleyiciyi çevreleyen durumlara göre farklı şekilde kullanılmaktadır. Nezaket kuralları toplumdan topluma değişiklik gösterse de ortak düşünce insanlar tarafından pratik bir şekilde uygulanmasidir.

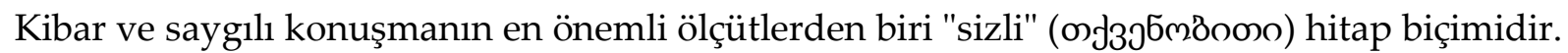
$\mathrm{Bu}$ durumda, ast ile üst ilişkisine göre, konuşmacı muhatabına karşı mütevazı olmalı ve ona saygı duymalıdır. Örneğin muhatabınızın tek kişi olduğunu varsayarsak normal şartlarda bu durumda karşınızdaki kişiyle konuşurken "senli" hitap biçimini kullanmanız gerekmektedir. Ancak ast üst ilişkisine göre muhatap bazen birden fazla kişi gibi görülebilmektedir. Böyle bir durum söz konusu olduğunda ise "sizli" hitap biçimi kullanılmaktadır. Özetle bu bağlamda muhataba siz statüsü kazandırılmaktadır.

Türk ve Gürcü kültüründe yeni tanışılan birine sadece adıyla hitap etmenin yaygın olmadığını vurgulamak gerekmektedir. Bir kişiye kibar bir şekilde hitap etmenin birçok türü vardır ve bunların arasında hanımefendi+ beyefendi ve kişinin soyadı veya adı gibi hitap biçimleri bulunmaktadır. Örneğin, unvan + kişinin adı hitap biçimi olarak iş görüşmelerinde, işte, doktor-hasta ilişkilerinde vb. yerlerde kullanılmaktadır. Başka bir deyişle ifade etmek gerekirse konuşmacılar arasında resmiyet ve mesafe gerektiren tüm durumlarda kullanıldığ görülmektedir. İki dilde sözlü ya da yazılı iletişimde kullanım yeri olarak şu şekilde farklılaşma vardır (๓øybsdy, 2006, s. 52- 73). Gürcücede hanımefendi/ beyefendi+ kişi ismi/ unvan, Türkçede kişi ismi+ hanımefendi/ beyefendi ya da unvan + kişi ismi+ hanımefendi/ beyefendi gibi.

Mesela mesleklerde nezaket kurallarının ve hitap şekillerinin kullanımı ilginç özelliklere sahip olabilmektedir. Bu özelliklerden biri de Türk ve Gürcü toplumunda tıp camiası içerisinde de hitap biçimlerinin kullanılmasıdır. Aynı yaş ve statüdeki hekimler, eğer aralarında sizli bizli bir ilişki yoksa ve uzun süredir tanışıyorlarsa, birbirlerine sadece isimleriyle hitap etmektedir. Oysa yaşlı veya daha üst seviyedeki doktorlar, genç veya daha alt seviyedeki doktorlara, kişilerin adları/ unvan+ (kişi adı) kibar hitap biçimi hanımefendi/ beyefendi şeklinde hitap etmektedir. Gürcücede bu sıralama yukarıda bahsedilen şekilde değişmektedir.

Konuşmacılar arasında asimetrik bir ilişki olduğu durumlarda, yani aralarında hiyerarşik bir mesafe varsa, onların ilişkilerinde hiyerarşik bir nezaket sistemi işlemektedir. Buna göre üst 
seviyedeki yaşlı doktorlar, alt seviyedeki genç doktorlara yalnızca isimleriyle hitap etmektedir.

Her iki kültürde profesör ile öğretmenler, üniversite öğrencileri ve okul öğrencileri arasındaki ilişkilerde hitap biçimlerinin kullanılması da ilginçtir. Önceden öğretmenler öğrencilerine sınıfta soyadlarıyla hitap ederlerdi ve adlarını nadiren kullanırlardı (yabancılarda bu durum hala devam etmektedir). Şimdi ise sınıftaki öğrencilerin aynı adı taşıması üzerine karışıklığı gidermek maksadıyla hitap olarak soyadıyla seslenilmektedir. Öğrenciler, öğretmenler ve veliler arasındaki ilişki, tamamen bir hiyerarşik nezaket sistemine dayanmaktadır. Yüksek öğretimde de durum aynıdır. Profesörler/öğretmenler ve öğrenciler arasında kibar hitap biçimleri kullanılmaktadır.

\section{Sonuç}

Konuşmacılar tarafından doğru hitap biçimlerini seçmek, iletişimin doğru kullanılmasına, iletişim yeterliliğinin dikkate alınmasına, nezaket stratejileri bilgisine ve önemli faktörlerden biri olan konuşmacılar tarafından olumlu bir imaj yaratılmasına bağlıdır.

Dinleyicinin ya da alıcının dikkatini çekmek ve konuşmacının bağımsızlı̆̆ını veya sosyal mesafesini ifade etmek amacıyla sözlü veya yazılı olarak kullanılan bir dizi ses, kelime veya kelimeler kombinasyonuna hitap denmektedir. Hitap biçimlerinin asıl görevi iletişim ortamında alıcının dikkatini çekmektir. Dikkat çekme görevi genellikle cümlenin başında ortaya çıkmaktadır. Cümlenin sonunda ve ortasında bulunan hitap ise, esas olarak sosyal mesafeyi ifade etmektedir. İletişim sürecinin doğru yönetimi hitaba bağlıdır. Hitabın yanlış kullanılması iletişimi sekteye uğratacaktır. Hitap, iletişim sürecindeyken muhatap olunan kişinin hangi rolü oynaması gerektiğini gösteren bir tür işarettir.

Gürcücede yazılı ya da sözlü iletişimde hitaplar, seslenme hal eki işaretleriyle (o- v), sözcüklerle, uygun noktalama işaretleriyle, ünlemlerle ve tonlama ile ifade edilmektedir. Türkçede ise hitaplar, biçim bilgisi baz alınarak sözcük türleri içerisinde ünlem, edat ve cümle dışı öge başlıkları altında incelendiği görülmektedir.

Türk dilinde ve Gürcü dilinde hitap olarak kullanılan isimler geniş yer kaplamaktadır. Hitap biçimlerinin genellikle adla ifade edildiği tespit edilmiştir. Hitap olan kişi isimlerinin kullanılması, alıcının yaşına, statüsüne, cinsiyetine, bireylerle arasındaki yakınlık derecesine göre değişiklik göstermiştir. Sağlıklı bir iletişim sağlanması için bu koşulların dikkate alınması gerekli görülmüştür. İsimlerin tam halinin yanı sıra kısaltılmış halinin de yakın çevreler tarafından kullanıldığı belirlenmiştir. Günlük hayatta hitap olarak askeriyede ve okullarda kullanılan soyadlarının aynı zamanda sizli bizli diyaloglarda, köklü aile mensuplarına kullanılan seslenmelerde, ayrıca TV programlarında veya haberlerde resmiyet maksadıyla da kullanıldığı ifade edilmiştir.

Türk dilinde akrabalığı ifade eden terimler Gürcü diline nazaran daha zengindir. Gürcü dilinde bilindik akrabalık terimleri kullanılmaktadır. Türkçede akrabalık hitaplarını ifade etmek için birçok kelime kullanılmıştır. Bu akrabalık ilişkilerine verilen önemin, dile yansıması olarak görülmektedir. Hem Gürcüce hem Türkçede cinsiyet belirten dilbilgisi kategorisi yoktur. Sadece erkek ve dişi olarak ifade edilen kelimelerin mevcut olduğu tespit edilmiştir. Aynı zamanda cinsiyet belirten bazı kelimeler kibar hitap biçimleri açısından 
önemlidir. Hitap olarak nadiren karşılaşılan soyut isimler genellikle şiirlerde ve romanlarda kullanılmaktadır.

Muhataba ya da muhataplara hitap etmek kullanılan adıllar ikinci şahıs zamirleri sen ve sizdir. Gürcücede ikinci şahıs zamirlerinin (shen (sen)- (siz) tqven) son sesinin (n) çıkartılması sonucu belirli bir yapı oluşmaktadır ve bu yapının sıklıkla kullanıldığı görülmektedir. Konuşma dilinin özelliğinden dolayı ikinci şahıs zamirleri genellikle " $\mathrm{n}$ " sesinden ayrılmaktadır. Niteleme sıfatları aracılığıyla ifade edilen hitaplar olumlu ve olumsuz değerlendirme olarak verilmiştir. Bu değerlendirmelerin aile bireylerine ve yakın tanıdıklara hitap ederken kullanıldığı belirtilmiştir. Fiilin hitap biçimleri ekler aracılığıyla ve muhatabı işaret ederek yapılmaktadır. Bu ekler hem emir kipi hem istek kipi hem de nezaket anlamı içermektedir. Fiillerin emir biçimleri ünlem olarak da kullanılmaktadır.

İnsanlar tarafından pratik bir şekilde uygulanan nezaket toplumdan topluma değişiklik göstermiştir. Bir kişiye kibar bir şekilde hitap etmenin birçok çeşidi bulunmaktadır. Nezaket kurallarının ve hitap şekillerinin mesleklerde kullanılması onların ilişkilerinde hiyerarşik bir nezaket sistemi ortaya çıkarmıştır. İki dilde sözlü ya da yazılı iletişimde kullanım yeri olarak şu şekilde farklılaşma bulunmaktadır: Gürcücede hanımefendi/ beyefendi+ kişi ismi/ unvan, Türkçede kişi ismi+ hanımefendi/ beyefendi ya da unvan + kişi ismi+ hanımefendi/ beyefendi gibi.

Çalışmaya konu olan nezaket ve hitapların sadece buradakilerle sınırlandırılması doğru değildir. Geniş çaplı araştırmalar sonucunda daha farklı nezaket ve hitap biçimlerine erişileceğini belirtmek gerekmektedir.

\section{Bilgilendirme}

Bu çalışma, "Gürcüce ve Türkçe Hitap Biçimleri Sistemleri” başlıklı doktora tezinden üretilmiştir. 


\section{Kaynakça}

Aksan, D. (2004). Dilbilim Ve Türkçe Yazıları. İstanbul: Multilingual.

Alkan Ataman, H. (2018). Türkiye Türkçesinde Hitaplar. Samsun: Ondokuz Mayıs Üniversitesi, Sosyal Bilimler Enstitüsü, (Yayımlanmamış Doktora Tezi).

Ayverdi, İ. (2010). Misalli Büyük Türkçe Sözlük. İstanbul: Kubbealtı İktisadi İşletmesi.

Dragolovcanin, C. (1997). Tanzimat'tan Cumhuriyet'e Kadar Basılı Metinlerde Geçen Hitaplar, Unvanlar ve Akrabalık Adları. Ankara: Ankara Üniversitesi Sosyal Bilimle Enstitüsü. (Yayımlanmamış Yüksek Lisans Tezi).

Karadoğan Doruk, E. (2010). Etkili İletişim Becerileri. İstanbul: İstanbul Üniversitesi Açık ve Uzaktan Eğitim Fakültesi.

Karahan, L. (2010). Türkçede Söz Dizimi. Ankara: Akçă̆ Basım Yayın.

Kocaman, A. (2009). Söylem Üzerine. Ankara: ODTÜ Yayıncılık.

Korkmaz, Z. (2009). Türkiye Türkçesi Grameri Şekil Bilgisi. Ankara: Türk Dil Kurumu Yayınları. Longman Dictionary of Language Teaching And Applied Linguistics. (2010). Great Britain: Pearson Education Limited.

Oğuz, B. B. (2011). Orhun Yazıtlarında Hitap Biçimlerinin Toplumsal Dilbilim Açısından Bir Analizi. Icanas, Uluslararası Asya ve Kuzey Afrika Çalışmaları Kongresi Bildirileri Kitabı (s. 1203-1226). Ankara: Atatürk Kültür Dil ve Tarih Yüksek Kurumu Yayınları.

Quirk, R., Greenbaum, S. (1973). A University Grammar Of English,. London: Longman Publishing Group.

Yıldırım, N. (2017). Çağdaş Türk Yazı Dillerinde Kadına Yönelik Hitaplar. Uluslararası Türk Lehçe Araştırmaları Dergisi I/1, 123-137.

Zeyrek, D. (2009). Söylem Üzerine. Ankara: ODTÜ Yayıncılık.

Большой современный толковый словарь русского языка. (2012).

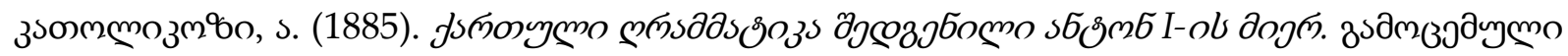

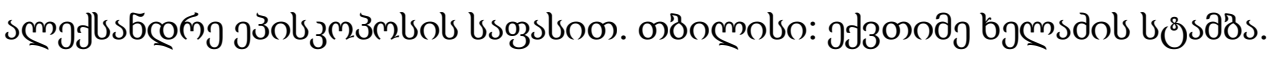

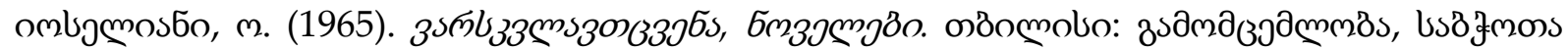

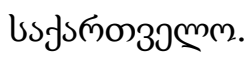

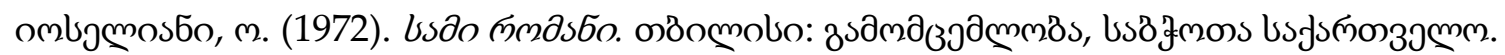

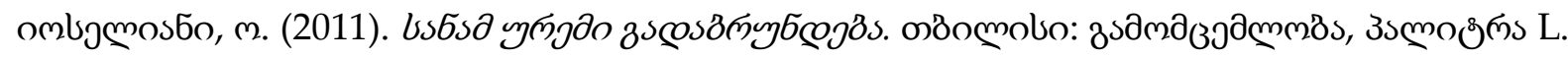

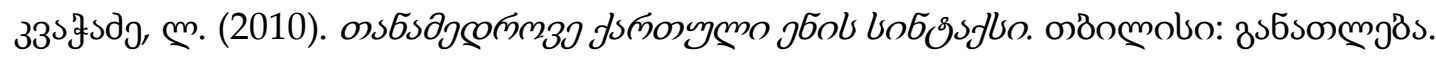




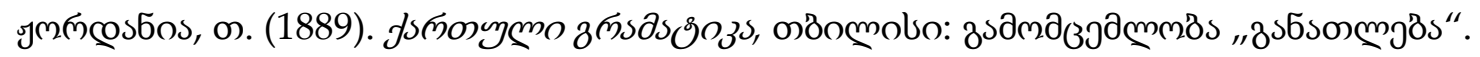

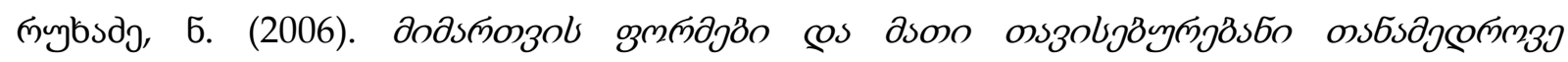

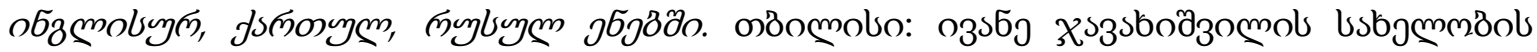

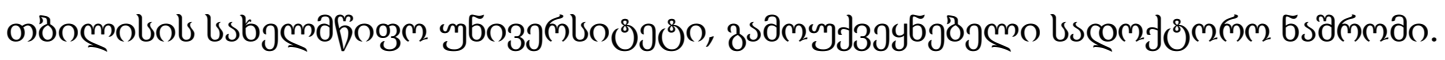

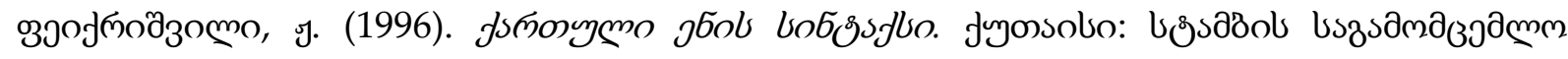

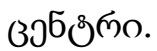

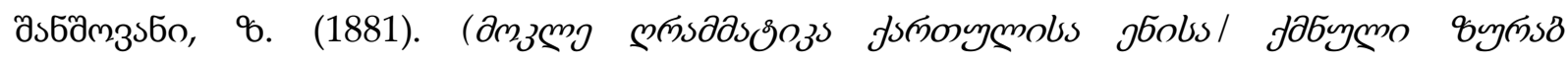

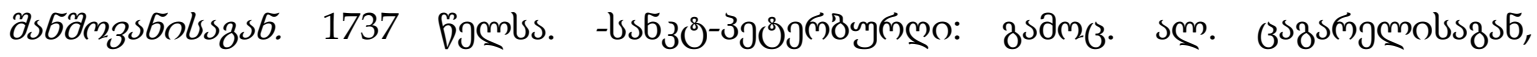

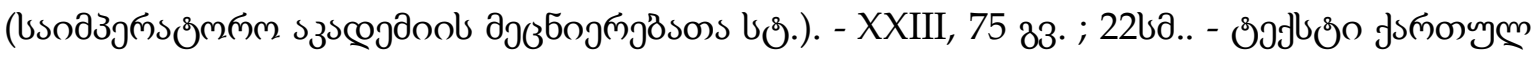

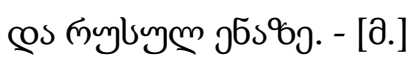

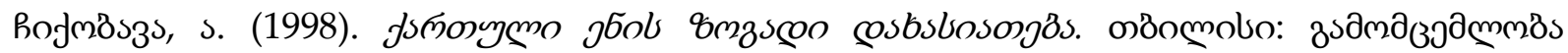

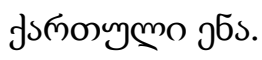

